DOI: 10.15740/HAS/IJPPHT/8.1/24-28

\title{
Preparation of Shrikhand by using banana pulp
}

\author{
A.P. Chaudhari*, Snehal Patinge and K.P. DhaKe
}

Department of Agricultural Process Engineering, Dr. Ulhas Patil College of Agricultural Engineering and Technology, JALGAON (M.S.) INDIA (Email : apchaudhari1 @ rediffmail.com)

\section{SUMMARY :}

Shrikhand is a popular fermented dish consumed by Indians during festivals and wedding occasions. Shrikhand is available in many varieties in the market with different flavors and aromas. Shrikhand is marketed with different brands and it is expected that quality of Shrikhand may vary. The present study was done on incorporation of ripened banana in Shrikhand. Banana Shrikhand sample was prepared in the laboratory. Different properties of banana Shrikhand were compared with that of branded Shrikhand. Then banana Shrikhand was subjected to various tests such as, chemical, nutritional, microbial and sensory. Banana Shrikhand is very good in taste and has better aroma than that of the standard brand of Shrikhand. Chemical, nutritional and microbial analyses are nearly equal to the standard brand. The result of sensory evaluation shows that banana Shrikhand is more acceptable because F-actual is greater than F-critical.

KEY WORDS : Banana Shrikhand, Physico-chemical, Sensory evaluation, Statistical analysis

How to cite this paper: Chaudhari, A.P., Patinge, Snehal and Dhake, K.P. (2017). Preparation of Shrikhand by using banana pulp. Internat. J. Proc. \& Post Harvest Technol., 8 (1) : 24-28. DOI: 10.15740/HAS/IJPPHT/ 8.1/24-28. 